\title{
The Effect of Corporate Governance on Financial Performance of Commercial Banks in Ghana
}

\author{
Alexander Owiredu \\ Mercy Kwakye \\ Department of Accounting and Finance \\ Pentecost University College \\ Ghana
}

\begin{abstract}
The study examined the influence of corporate governance principles on banks financial performance in Ghana. Data for the study was gathered from the annual reports and the financial statements of the sampled banks from the period 2007-2016. Random effect model was used to analyse the data. This study found a significant positive relationship between board size and financial performance measured by ROA and ROE of banks in Ghana. Additionally, the study found a statistically positive relation between foreign ownership and financial performance measured by ROE and ROE. Interestingly, the study outcome further indicated positive but no statistically relationship between board independence and institutional ownerships and ROA and ROE of the sampled banks in Ghana. Generally, the study supports the view that an improved corporate governance practices is key to increasing firm financial performance.
\end{abstract}

Index Terms:Corporate Governance, Financial Performance, Banks, Ghana

\section{Introduction}

Adherences to corporate governance principles and practices is one of the key catalyst to organizational efficiency and success. Therefore, submitting to good corporate governance principles and structures will not only aims at assisting in better monitoring and effective control of business, but shall also ensure a long term enhancement of firms' performance and sustainability (Ehikioya, 2009).

In Ghana, the upsurge in financial institutions failures and other fraudulent activities due to some of the reasons cited as unethical business practices among top level management in recent times, has put into question good corporate governance principles and best codes of practices of these institutions. These developments are progressively making corporate governance an important phenomenon in recent years. To effectively keep pace with the developed world on financial inclusiveness and strong financial markets, the need for compliance with corporate governance practices within the banking sector are more significant for competitiveness and increase in investors' confidence.

Among the significant element of corporate governance principles is the obligations conferred on a company board of directors in the areas of supervision, monitoring and determination of strategic direction of entities. However, Tornyeva T, Tura A. H., Fatim, B (2012) outlined in their studies that the incentives to appoint questionable and wrong persons into companies' boards is due to weak corporate governance structures and business culture. Jackson E (2012) also noted that governance difficulties confronting firms are mainly as a result of dubious individuals' presence on the board. Carter, D.A., D’Souza, F., Simkins, B.J. and Simpson, W.G. (2007). established a negative relationship between corporate performance and shareholder value and cited bad corporate governance as the main basis of the findings.

Generally, corporate governance is becoming a present-day subject due to its tremendous impact to economic growth and development Tornyeva and Wereko (2012). Poor corporate governance structures have a long term effect of diminishing public trust within the organizational system, particularly banking system. Consequently, it could bring about firms' failures, thereby impacting negatively on any economy. This is because in the views of Gul, S., Irshad, F. \& Zaman, K. (2011), in corporate governance studies, board composition is seen as a vital ingredient that affects not only board effectiveness but also how the board undertake its role.

Studies (see Tornyeva and Wereko (2012); Afolabi, A. A. (2013) hold the view that good corporate governance practices such as prudent distribution of firm's resources and competent management among others help to improve firms' performance. In recent times. concerns have been raised about the governance structure of financial systems, largely as a result of upsurge in corporate scandals, resulting in a declining shareholder value, dimmed investor confidence and bank failures (Klapper \& Love, 2004). 
Research in this field gain the interest of the researchers due to the fact that banking industry is viewed by policy makers and industry players as one of the vital sectors to economic growth. In supporting this position, the IMF country report (2014) and Ghana Statistical Service, (2014), asserted that the banking assets constituted about 75\% (GHC 51.4 billion) of the total financial assets as at December, 2014. Hence, any failures of the banking sector would put the economy of Ghana in a huge problem. The corporate governance of banks in Ghana is important for several reasons. However, among the studies in corporate governance in Ghana (see David Adeabah, AgyapomaaGyeke-Dako, Charles Andoh, 2018; Beatrice Sarpong- Danquah, Prince Gyima, Richard OwusuAfriyie and Albert Asiamah, 2018)., none has focused on the effect of corporate governance on financial performance of banks. Studies on the relationship has been done in other countries with mixed result (see Chaghadari2011, andDrobetz, Schillhofer and Zimmermann, 2011)

It could be observed from the reviewed studies that there are inconclusive findings and conclusions and hence, the need to find out whether any association exist between corporate governance and financial performance of the commercial banks in Ghana. Thus, this study seeks to add to the debate by making it clear from a Ghanaian perspective whether corporate governance structures (e.g. board size, board independence, duality of CEO, institutional ownership and foreign ownership) have any nexus on banks' performance. The proposed study besides filling these research gaps will also contribute to the policy and development of bank governance structures in Ghana. This study seeks to address the gab by using data from commercial banks in Ghana to investigate the association between corporate governance and financial performance of Ghanaian banks for the period 2007 to 2016.

The paper is structured into the following sections. Section one (1) shall discuss the background of the study. Section two (2) shall outlie the reviews of existing literature on the subject matter, while section three (3) discusses the methodology for the study. Finding and discussions of the impact of corporate governance on firms' financial performance is reported in section four (4) followed by conclusion and policy implications, limitation and future research direction of the study.

\section{Literature Review}

Several theories including resource dependency theory, agency theory and stakeholder theory explain the interactions between financial performance and corporate governance. These theories according to Zgarni, Hiloui\&Zehri, (2016), have been widely recognized as theoretical basis underpinning research in financial accounting and corporate governance.

The adoption of Agency theory for this study is grounded on the premise that, a review of the theoretical dimensions showed that studies on corporate governance and financial performance of firms could aptly be elucidated through the principles of thetheory. Again, because the study exhibits a principal-agent link form, the application of agency theory principles is unquestionable a potent theory to be used. Agency theory is premise on the grounds that practically a sizeable number of corporate managers are not owners, rather they are agents of the owners who are engaged to manage the company on the managers' behalf (Ujunwa et al., 2012). According to Elsayed, (2007) and Kang \&Zardkoohi, (2005) where same persons occupy dual positions, then monitory role conferred on the board of directors may be narrowed and consequently have a negative impact on the performance of the firm. The study further cited loss of board independence due to duality function of same CEO as a key reason that may account for the limit in the monitory role by the board. These arguments as put forth by the agency theory in the position of Kiel \& Nicholson, (2003) is grounded on the belief of element of possible basic conflict of interest between the owners and managers of the company.This theory supports our hypothesized effect of Corporate Governance on Financial Performance

\section{Board size and Financial Performance}

Board Size has received greater consideration in most corporate governance literature. Findings for prior studies on the link between board size and bank performance have been inconclusive. The findings ranges from positive, negative, and concave [Salim et al. (2016), Pathan and Faff (2013), and Grove et al. (2011)]. Additionally, whereas some authors [(see Sheikh et al., (2012), Adams and Mehran, (2012)] have found a positive relationship, others including (Staikouras et al., (2008); Wang et al., (2012)) have found either no relationship or negative relationship (see Wintoki et al., 2012; Andrest et al., 2005). Several reasons including the bank performance measure (i.e. Tobin Q, ROA, ROE) (Owen and Temesvary, 2018), the structure of board (i.e. larger boards or smaller boards) Haniffa \& Hudaib, (2006), the economic environment (Coles et al., 2008) and endogeneity problems (Wintoki et al., 2012). have been cited for the mixed findings. Haniffa \& Hudaib, (2006) further argued that large board size is linked with multiplicity in skills, business contacts and experience than smaller boards size. They therefore concluded that large board size provides huge opportunity to obtain essential resources. 


\section{Non-Executive Directors and Financial Performance}

Board independence has become an increasingly indispensable subject in the corporate governance practices. Evidence from prior studies indicated that board independence enriches monitoring thereby helps in adding value to the fiduciary responsibility of the board. (Jensen and Meckling, 1976). Similarly, Andres and Vallelado, (2008) noted that the presence of independent directors reduces management aperture for giveaways which interns helps to improves bank performance. Chizema and Kim, (2010) opines that agency costs between management and shareholders is mitigated especially when entities are dominated by a greater percentage of outside directors on a board. In line with agency theory, the non-executive directors are foreseen as important monitors that supervise and control the executives. These position were confirmed by Staikouras-et-al., (2008) who after examining 58 large European banks over the period 2002- 2004, concluded that board composition is positively related to both return on assets (ROA) and return on equity (ROE).

On the other hand, other studies (Babatunde and Olaniran (2009); Fernandes and Fich (2010); Ehikioya (2009) and Belkhir (2009)] found no significant evidence supporting the position that the presence of independent directors help in promoting firm performance.

Despite the above considerations, our agency theory viewpoint as supported by Fama, \& Jensen, (1983) is that independent directors are better placed than executive directors perform monitoring function better as they are probably independent and as such more concerned for their reputation in the labour market.

Specifically, we take the position that with a relatively seemingly weak corporate governance environment in developing world like Ghana, the economic sense for board independent is justifiable. Therefore, the second hypothesis on board independence is sated as:

\section{Board Chairman Positions and the Separation of CEO and Financial Performance}

The position of agency theory is that Board Chairman and CEO positions or roles should be separated and held by different people. According to Jensen (1986), if the positions are not separated and an individual hold both positions, that individual is likely to take business decisions on personal interest, thus causing financial performance to fall. This position was held by Chang and Abu Mansor (2005) in their investigation on the impacts of good corporate governance practices on the performance of 120 listed companies in Malaysia during the 1997 Asian financial crisis and concluded that a higher financial performance is usually associated with firm where both positions are held by different people. Dahya, Lonie\& Power, (1996) and Christensen, Kent \& Stewart, (2010) argued that straightforward leadership occasioning from CEO duality enables the CEO make decisive decide on strategic vision with firms having fewer board interference, thereby leading to increasing financial performance.

\section{Foreign ownership and financial performance}

Within the emerging markets, the influence of foreign ownership on firm financial performance is increasingly becoming a material interest to academics, industry players and policy makers. Past studies have established mixed results between foreign ownership and bank performance (Al Manaseer et al., 2012; Kim and Rasiah, 2010; Lawer Tetteh, 2014; Majnoni et al., 2003). Studies by Al Manaseer et al., (2012) and Opoku-Agyeman (2015) found a positive impact on the relationship between foreign ownership on bank performance. These authors cited improved monitoring and superior technologies associated with banks owned by foreigners operating in developing and transitional economies. On the contrary, Ntow and Laryea-Afoley (2012) reported a negative relationship between foreign ownership on financial performance among 25 Ghanaian banks over the period 2005-2010. Ntow et al (2012) disclosed that the negative relationshipis due to inadequate knowledge on the Ghanaian terrain. In spite of the contrary views, Aydin,Sayim and Yalama, (2007) established that, on average, foreign owned companies are doing better financially than the institutions owned by the indigenes. This to an extent can be true, given the ability of most of the foreign owned bank in Ghana surviving the bank of Ghana financial sector clean up.

\section{Ownership Structure and Financial Performance}

Organization ownership is a significant facet of corporate governance structure, which according to Long et al, (2013) could potentially influence how firms performs financially. Thus, when institutions become part of the ownership structure of a firm, its representation on the board shall be apt, due mainly to the fact that the institutions are more able to provide the needed supervision and leadership skills necessary to ensure financial sustenance and growth. Claessen and Yurtoglu (2012) did a study in Czech Republic and found a statistically strong positive relationship between organization market value, financial performance and ownership concentration. Similarly, Holderness and Sheehan (1988) also established an indirect effect of share ownership concentration on companies' performance. 


\section{Research hypothesis}

Based on the review literature, the study raises the following hypothesis:

H1a and b: Board size and bank financial performance(measured by ROE and ROA) in Ghana are statistically positive related

H2a and b: Financial performance (measured by ROE and ROA) and non-executive directors are statistically positive related

H3a and b: Board chairman positions and the separation of CEO and financial performance (measured by ROE and ROA) are statistically positive related

H4a and b: A positive relationship exists between foreign ownership and financial performance (measured by ROE and ROA) of banks in Ghana.

H5a and b: The financial performance (measured by ROE and ROA) and ownership structure of banks in Ghana are positively related.

\section{Methodology}

The target population for the study was all the thirty-two (32) commercial banks in Ghana (BOG,2016). In the end ten (10) commercial banks representing $31.25 \%$ were chosen for the study. These selected banks were those in existents for the past 10 years and also, have on available the financial statement covering the said period. Secondary data using annual reports for the period 2007-2016 was used for the study. The data collection period lasted for two months (June 2018-august 2018). In order to examine the relationship between corporate governance and financial performance, this study analyse a model comprising of financial performance indicator (as the dependent variable) and selected corporate governance indicators (as the independent variables). The financial performance indicators used for the study were ROA and ROE and the corporate governance indicators included, board size (Black, 2002), board independent directors (Kaur and Mishra, 2010; Annalisa, P. \& Yosef, 2011) as independent variables and variables such as firm size and age and tangibility of assets as controlled variables. These variables were manually collected, collated and computed from the annual report.

\section{Model Specification}

In order to determine the influence of corporate government on financial performance, we mathematically formulated our model in the form:

$\operatorname{Perf}_{i t}=\beta X_{i t}+C_{i t}+\mu_{i t}$

Where:

$\operatorname{Per} f_{i t}=$ the financial performance of firm i in time $\mathrm{t}$;

$X_{i t}=$ a vector of board characteristics of firm $\mathrm{i}$ in time $\mathrm{t}$;

$\beta=$ a coefficient of board characteristics

$C_{i t}=$ a set of control variables of firm $\mathrm{i}$ in time $\mathrm{t}$;

$\mu_{i t}=$ stochastic disturbance term

Specifically, we restate the model as follows;

$R O E_{i t}=\beta_{0}+\beta_{2} B S I Z E_{i t}+\beta_{3} B I N D_{i t}+\beta_{4} C E D_{i t}+\Delta_{1} F R W_{i t}+\Delta_{2} I N W_{i t}+C_{i t}+\mu_{i t}$

$R O A_{i t}=\beta_{0}+\beta_{2} B S I Z E_{i t}+\beta_{3} B I N D_{i t}+\beta_{4} C E D_{i t}+\Delta_{1} F R W_{i t}+\Delta_{2} I N W_{i t}+C_{i t}+\mu_{i t}$

The variables in the model are defined as follows:

- $\quad \mathrm{ROA}=$ Return on Asset and is measured by the ratio or percentage of net profits to total assets. This is a dependent variable for the study and its used to assess the banks performance. It has been used in several studies as a measure of performance (see Capraru\&Ihnatov, 2015; Menicucci and Paolucci, 2016)

- $\quad \mathrm{ROE}=$ Return on Equity and is measured by ratio of percentage of net profits to shareholders' equity

- $\quad$ BSIZE $=$ Board Size and is measured by the Number of directors on the board

- $\quad$ BIND $=$ Board independence and is measured by Number of non-executive directors on the board

- $\mathrm{CED}=$ Role of $\mathrm{CEO}$, takes a dummy variable that equals 1 if the $\mathrm{CEO}$ is the board's Chairman and 0 otherwise

- $\mathrm{FRW}=$ Foreign Ownership, takes a dummy variable that equals 1 if the firm is foreign-owned and 0 for a Ghanaian-owned firm.

- $\quad$ INW= Institutional Ownership is measured by proportion of shares institutions hold

- $\quad$ FSIZE = Firm size in terms of total assets owned and is measured by the log of total assets. This variable is deemed as a predictor of performance and has therefore been used by many researchers for similar studies (Gul, Irshad\& Zaman, 2011; Menicucci\&Paolucci, 2016, Bokpin,2013). 
- $\quad \mathrm{FAGE}=$ Age of firm and is measured by number of years between year of incorporation and Observation year.

- $\quad \mathrm{ATA}=$ assets tangibility (Fixed asset base of firms) measured by the ratio of fixed asset to total assets

\subsection{Findings and Discussions}

\subsection{Descriptive Statistics}

The descriptive statistics for the study provided on table 1 are as follows:

Table 1: Descriptive Statistics

\begin{tabular}{llllll}
\hline Variable & Obs. & Mean & Std. Dev. & Min & Max \\
\hline Return On Assets & 100 & 0.03 & 0.02 & $(0.10)$ & 0.11 \\
Return On Equity & 100 & 0.24 & 0.15 & $(0.24)$ & 0.82 \\
Board Size & 100 & 8.30 & 1.56 & 6.00 & 11.00 \\
Ceoduality & 100 & 0.00 & 0.00 & 0.00 & 0.00 \\
Board Independence & 100 & 0.76 & 0.07 & 0.60 & 0.86 \\
Foreign Ownership & 100 & 0.50 & 0.50 & 0.00 & 1.00 \\
Institutional Ownership & 100 & 0.60 & 0.49 & 0.00 & 1.00 \\
Firm Age & 100 & 21.00 & 16.81 & 10.00 & 62.00 \\
Firm Size & 100 & 5.86 & 5.52 & 3.74 & 6.82 \\
Asset Tangibility & 100 & 0.03 & 0.03 & 0.00 & 0.24 \\
\hline
\end{tabular}

The test results as shown on Table 1 indicates a mean score of 0.24 (24\%) for ROE during the period 2007-2016. During the same period, the standard deviation score of 0.15 , was less than 1.00 , suggesting a little variation in bank profits.

The Board size average score of 8.30 suggests that on average, banks in Ghana within the study period have 8 persons on their board. However, the standard deviation value of 1.56 specifies a wide variability in the boards' size.

The number of Chairman who held CEO position in banks in Ghana is represented by a mean value of 0.00 . The implication of the outcome points to the fact that, in Ghana, CEOs are not the board Chairman of banks. That is to say, appointing a same person for both Chairman and CEO positions is not common in Ghana especially in the banking industries. The standard deviation score of zero shows that the members consent to whoever heads the board apart from the CEO. This conform to the regulatory requirement in Ghana where within the banking sectors, CEO are not board chairmen.

The average score 0.76 for the board independence suggest that non-executive director constitute on average $76 \%$ of total board size. With the mean eight (8) persons constituting the board size, the findings did indicate at least six (6) members on the boards are independent directors. The high proportion of independent board members on the board is not only a good sign for board efficiency and effectiveness but also an indication of a growing awareness of the importance of board independence in enhancing financial performance of financial institutions in Ghana. However, 0.07 standard deviation suggests highly diversified non-executive directors.

The ownership structure average score indicates that at least half of the total selected banks are locally owned. The recorded low standard deviation of 0.50 suggests low in variability for ownership structure.

The institutional ownership average figure of 0.600 implies the presence of institutional ownership in most of the banks in Ghana. However, a low standard deviation of 0.49 suggests low multiplicity in institutional ownership.

The average of 3\% of assets tangibility implies that banking firms in Ghana have large proportion of the assets in current assets. However, standard deviation of 0.03 points to cash flows concerns of most banks. 
On average, the age of the sampled banks of 21 years, suggest that the banks in Ghana have been operating for years. The standard deviation value of 16.81 is high, indicating that these banks vary substantially in years of existence.

The average figure of 5.86 representing the total assets of the sampled banks are within the acceptable level. This suggests that the sampled banks have adequate total assets base requirement for generating better returns. However, the standard deviation of 5.52 implies huge differences in total assets. of banks'

Table 2: Random Effect Results with ROE and ROA as Dependent Variables

\begin{tabular}{|l|l|l|l|l|l|}
\hline & \multicolumn{2}{|c|}{ Return On Equity } & \multicolumn{2}{c|}{ Return On Assets } \\
\hline Independece Variable & \multicolumn{1}{|c|}{$\beta$} & P-value & $\beta$ & P-value \\
\hline BSIZE & $0.029^{* *}$ & 0.008 & $0.004^{* *}$ & 0.035 \\
\hline BIND & -0.124 & 0.606 & 0.047 & 0.203 \\
\hline FRW & $0.168^{* * *}$ & 0.001 & 0.015 & 0.054 \\
\hline INW & 0.041 & 0.308 & -0.004 & 0.501 \\
\hline FAGE & 0.002 & 0.252 & 0 & 0.655 \\
\hline FSIZE & -0.061 & 0.111 & 0.001 & 0.92 \\
\hline ATA & -0.214 & 0.748 & 0.187 & 0.07 \\
\hline _cons & 0.304 & 0.281 & -0.052 & 0.237 \\
\hline R-square (within & 0.0318 & & 0.0305 & \\
\hline R-square (between) & 0.9263 & & 0.9183 & \\
\hline R-square (overall) & 0.204 & & 0.226 & \\
\hline Wald Chi2 & 23.57 & & 26.87 & \\
\hline Number of obs. & 100 & & 100 & \\
\hline Number of groups & 10 & & 10 & \\
\hline legend: * p<0.05; ** p $<0.01 ; * * * 0.001$ & & & \\
\hline
\end{tabular}

Results from table two (2) reveals that, board size (BSIZE) is found to have a significant relationship ( $\mathrm{p}<0.05)$ with both the ROE, and ROA. The result also indicates that board size is positively related to both ROE and ROA, which is in agreement with the findings of Adusei (2010) and Ghazaleh et al (2012). The positive result may suggest that banks in Ghana with bigger board size is able to generate higher market value due to range of ideas from the experts on the board. Kiel and Nicholson (2003), affirms the position and deduced that central role board size plays in accomplishment of the viability of the board and an enhancement of performance of the firm. Further, the results for board independence (BIND) and Institutional Ownership (INSOW) are not significantly related ( $\mathrm{p}>0.05$ ) to both independent measurement variables ROE and ROA. Board independence (BIND) is positively related to ROA but negatively related to ROA. This is consistent with Staikouras-et-al., (2008) but contradict with (Babatunde and Olaniran (2009); Fernandes and Fich (2010) found no significant evidence supporting the position that the presence of independent directors helps in promoting firm performance. The outcome may suggest that Banks in Ghana that have a greater number of independent directors may have better financial performance measured by both ROE and ROA. 
The result for CEO duality (CDUAL) was omitted due to collinearity for both ROE and ROA. The results affirm the position in Ghana where BOG frowns on duality function of board chairpersons.

Results for Foreign Ownership (FRW) is found to have a significant $(\mathrm{p}<0.001)$ positive relationship with ROE but insignificant relation with ROA. This is inconsistent with Ntow and Laryea-Afoley (2012), who argued that foreign owners may not enhance profit due to the lack of knowledge in the area of operation. However, given the fact that the age of the banks in operation for this study is high and the fact that other variables may contribute to performance, their outcome can be disputed. It is therefore not a coincidence that Al Manaseer et al., (2012) and Opoku-Agyeman (2015) findings supported the findings of the study. The positive relationship may suggest that the banks owned by foreigners may perform better financially in Ghana. This could be due to high capital injections and board effectiveness.

Institutional Ownership (INW) is negatively related to ROA but positively related to ROE. This implies the shares that institutions hold in firm does not have any positive relationship with the performance of a firm measured by ROE. However, measuring using ROA gave an opposite outcome. Claessen and Yurtoglu (2012), findings supported the positive relation.

The control variables, apart from the asset tangibility that is found to be significantly related $(\mathrm{p}<0.05)$ ROA, none of the other variables shows a significant relationship to ROE and ROA. The positive coefficient FSIZE relationships contradicts the findings of Christensen et al. (2006), MohdGhazali (2010), and San and Heng (2011). The findings of these authors suggest that smaller firms are highly associated with better financial performance. The result indicates in Ghana, bigger firms are more efficient and innovative thereby tend to utilize its financial resources in a manner that help in generating a higher financial performance.

\subsection{Conclusion and Further Research Directions}

The paper examined the link between corporate governance structures, including board size; board independence; Foreign Ownership; and institutional Ownership, and the financial performance of Ghanaian banks, measured by ROE and ROA.

Our study revealed that board size is positively associated with financial performance measured by both ROE and ROA. The outcome suggest that larger board are deemed wide range of expertise and knowledge related to banking firms that is key for firms' sustainability and growth in financial performance.

Further, we established banks in Ghana have a higher presence of independent directors on the board and the association is positively correlated with financial performance. The findings support agency theory proposed by Fama and Jensen (1983) which suggest that the presence of independent director are central in monitoring the activities of the board so as to help in preventing the possible misuse of resources with the view to maximize shareholder's wealth.

The results established foreign ownership has a positive relation with performance. Although not statistically significant relationship, the improvement in financial performance as a result of foreign owners may suggest that foreign investors can provide the organization with managerial talent and access to the financial resources necessary to improve organizational performance.

The study outcome could assist bank of Ghana (BOG) to fashion out a governance structure that can enhance banking practices in Ghana. Also, coming up with a governance structure that improves financial performance is critical for policy makers and stakeholders in the financial sector.

Future research should include more banks since the current work was limited to only ten banks with at least ten years in operation. That means other banks that has been in operations for less than ten (10) were excluded. Other governance variable such as board meetings and audit committees were ignored. As a result, drawing generalization about the outcome of the study is problematic

\section{ACKNOWLEDGMENT}

The authors wish to thank Pentecost University College, Ghana. This work was supported in part by a grant from Pentecost University College, Ghana.

\section{REFERENCES}

Adams, R. B., \& Mehran, H. (2012). Bank board structure and performance: Evidence for large bank holding companies. Journal of Financial Intermediation, 21(2), 243-267. http://dx.doi.org/10.1016/j.jfi.2011.09.002

Adusei, M. (2010). Board structure and bank performance in Ghana. Journal of Money, Investment \& Banking, 19, 7284 
Afolabi, A. A. (2013). The key challenges of the corporate governance of firms: Empirical evidence from Sub-Saharan African Anglophone (SSAA) countries.

Beatrice Sarpong-Danquah, Prince Gyimah, Richard Owusu Afriyie1 \& Albert Asiamah (2018) Corporate Governance and Firm Performance: An Empirical Analysis of Manufacturing Listed Firms in Ghana Accounting and Finance Research Vol. 7, http://afr.sciedupress.com

Al-Manaseer, M. F., Al-Hindawi, R. M., Al-Dahiyat, M. A., \&Sartawi, I. I. (2012).The Impact of Corporate Governance on the Performance of Jordanian Banks. European Journal of Scientific Research, 67(3), 349-359.

Andres, P.D. and Vallelado, E. (2008), "Corporate governance in banking: the role of the board of directors", Journal of Banking and Finance, Vol. 32 No. 12, pp. 2570-2580.

Andres, P.D., Azofra, V. and Lopez, F. (2005), "Corporate boards in OECD countries: size, composition, functioning and effectiveness", Corporate Governance: An International Review, Vol. 13 No. 2, pp. 197-210.

Annalisa, P. \& Yosef B, (2011). Corporate governance and earnings management in family-controlled companies. Journal of Accounting, Auditing and Finance, 26(2), 199-227. doi: 10.1177/0148558X11401212

Aydin, N., M. Sayim and A. Yalama, 2007. Foreign ownership and firm performance: Evidence from Turkey. Int. Res. J. Finance Econ., 11: 103-111.

Babatunde, M. A. \&Olaniran, O. (2009). The effects of internal and external mechanism on governance and performance of corporate firms in Nigeria. Corporate Ownership \& Control, 7 (2), 330-344. [16].

Belkhir, M. (2009) Board of director's size and performance in banking, International Journal of Managerial Finance, 5

Black BS (2002) The non-correlation between board Independence and long-term firm performance. Journal of Corporation Law 27:231-274

Bokpin, G.A. (2013), "Ownership structure, corporate governance and bank efficiency: an empirical analysis of panel data from the banking industry in Ghana", Corporate Governance: The International Journal of Business in Society, Vol. 13 No. 3, pp. 274-287.

Capraru, B., Ihnatov, I. (2014), Banks' profitability in selected central and Eastern European countries. Procedia Economics and Finance, 16, 587-591

Carter, D.A., D'Souza, F., Simkins, B.J. and Simpson, W.G. (2007). The Diversity of Corporate Board Committees and Financial Performance. available at http://ssrn.com/abstract1/41106698/ (accessed 7 August 2009).

Chaghadari, M.F. (2011). Corporate Governance and Firm Performance. International Conference on Sociality and Economics Development, 10,484-489.

Chang, A. L. A., \& Abu Mansor, S. (2005). Can good corporate governance practices contribute to firm's financial performance? Evidence from Malaysian companies. International Journal of Business, Governance and Ethics, Vol. 1 (4), pp. 350-362.

Adeabah, David and Gyeke-Dako, Agyapomaa and Andoh, Charles, Board Gender Diversity, Corporate Governance and Bank Efficiency in Ghana: A Two-Stage Data Envelope Analysis (DEA) Approach (September 17, 2018). Corporate Governance, Forthcoming. Available at SSRN: https://ssrn.com/abstract=3312103 or http://dx.doi.org/10.2139/ssrn.3312103

Christensen, J., Kent, P., \& Stewart, J. (2010). Corporate Governance and Company Performance in Australia. Australian Accounting Review, Vol. 20 (4), pp. 372-386.

Chizema, A. and Kim, J. (2010) Outside Directors on Korean Boards: Governance and Institutions: Journal of Management Studies, 47, pp109-129

Claessens, S. \&Yurtoglu, B. (2012). Corporate Governance and Development: An Update. Focus 10, global corporate governance network

Coles, J.L., Daniel, N.D. and Naveen, L. (2008), “Boards: does one size fit all?”, Journal of Financial Economics, Vol. 87 No. 2, pp. 329-356.

Dahya, J., Lonie, A. A., \& Power, D. M. (1996). The Case for Separating the Roles of Chairman and CEO: An Analysis of Stock Market and Accounting Data. CorporateGovernance-AnInternational Review, Vol. 4, pp. $71-77$.

Drobetz, W., Schillhofer, A., \&Zimmermann, H. (2011).Corporate governance and firm performance: Evidence from Germany.

Ehikioya, B.I. (2009) Corporate Governance Structure and Firm Financial Performance in Developing Countries. Evidence From Nigeria. Corporate Governance. An International Review, 9 (3) pp231-243.

Elsayed, K. (2007), Does CEO Duality Really Affect Corporate Performance, CorporateGovernance: An International Review, 15 (6): 1203-1224

Fama, E. \& Jensen, M. (1983). Separation of ownership and control. Journal of Law Economics, 26(2), 301-325. 
Grove, H., Patelli, L., Victoravich, L.M. and Xu, P. (2011), "Corporate governance and performance in the wake of the financial crisis: evidence from US commercial banks", Corporate Governance: An International Review, Vol. 19 No. 5, pp. 418-436.

Gul, S., Irshad, F. \& Zaman, K. (2011). Factors affecting bank profitability in Pakistan. The Romanian Economic Journal, 13(39), 61-87.

Haniffa, R., \&Hudaib, M. (2006). Corporate Governance Structure and Performance of Malaysian Listed Companies. Journal of Business Finance \& Accounting, Vol. 33(7), pp. 1034-1062.

Jackson E (2012). CEO compensation and firm Performance: Journal of Business and Economics Research, 6, 84-98.

Jensen, M.C. and Meckling, W.H. (1976), "Theory of the firm: managerial behavior, agency costs and ownership structure", Journal of Financial Economics, Vol. 3 No. 4, pp. 305-360.

Kang, E. \&Zardkoohi, A. (2005). Board Leadership Structure and Firm Performance. Corporate submitted to the Centre for Strategic Economic Studies, Faculty of Business and Law, Victoria University, Melbourne.

Kaur, G \& Mishra, R (2010), 'Corporate governance failure in India: A study of academicians' perception', The IUP Journal of Corporate Governance, vol. 9, no. 1, pp. 99-112.

Kiel, G. \& Nicholson, G. (2003). Board Composition and Corporate Performance: How The Australian Experience Informs Contrasting Theories of Corporate Governance. Corporate Governance: An International Review, 11 (3), 189-205.

Kim, P.K. and Rasiah, D (2010), Relationship between corporate governance and bank performance in Malsysia during the pre and post Asian Financial Crisis, European Journal of Economics, Finance and Administrative Sciences, $21 \mathrm{pp} 39-63$

Klapper LF, Love I (2004) Corporate governance, investor protection, and performance in emerging markets. J Corp Finan 10(5):703-728

Tetteh, M.L (2014) Local versus Foreign bank performance: The Case of Ghana. Banks and Bank Systems Vol (9) 4350.

Long, C. S., G. R. Mahanra and M. A. Ajagbe (2013). Can employee share option scheme improves firm's performance? A Malaysian case study. Information Management and Business Review, 5(3), 119-128.

Majnoni, G, Shankar, R and Várhegyi, E. (2003). The dynamics of foreign bank ownership: evidence from hungary. 2003. World Bank Policy Research Working Paper 3114,

Menicucci, E. \&Paolucci, G. (2016). The determinants of bank profitability: Empirical evidence from European banking sector. Journal of Financial Reporting and Accounting, 14(1), 86-115.

MohdGhazali, N. A. (2010). Ownership structure, corporate governance and corporate performance in Malaysia. International Journal of Commerce and Management, Vol. 20 (2), pp. 109-119.

Ntow - Gyamfi Matthew LaryeaAfoley Esther (2012) International Journal of Business and Social Science Vol. 3 No. 21; November 201282 A Financial Performance Comparison of Foreign VS Local Banks in Ghana

Ntow- Gyamfi, M. \&Laryea- Afoley, E. (2012) A Financial Performance Comparison of Foreign Banks and Local Banks in Ghana. International Journal of Business and Social Science, 3 (21) pp82-85

Owen, Ann L. \&Temesvary, Judit, (2018). "The performance effects of gender diversity on bank boards," Journal of Banking \& Finance, Elsevier, vol. 90(C), pages 50-63.

Opoku-Agyemang (2015). Factors influencing the profitability of domestic and foreign banks in Ghana. Unpublished Master Thesis, School of Business and Social Sciences, AARHUS University

Pathan, S., Faff, R., (2013). Does board structure in banks really affect their performance? J. Bank. Finance37, $1573-1589$.

Salim, R., Arjomandi, A. \&Seufert, J. Heinz. (2016). Does corporate governance affect Australian banks' performance?. Journal of International Financial Markets, Institutions and Money, 43 113-125

San, O.T., and Heng, T.B. (2011). Capital Structure and Corporate Performance of Malaysian Construction Sector. International Journal of Humanities and Social Science, 1(2), 28-36.

Sheikh, N. A., \& Wang, Z. (2012). E (2012), "Effects of corporate governance on capital structure: empirical evidence from Pakistan", Corporate Governance, Vol. 12 No. 5, pp. 629-641. https://doi.org/10.1108/14720701211275569

Staikouras, C,Mamatzakis, E, \& K Outsmanoli-Fillipaki, A.(2008), Cost Efficiency of the banking industry in the South Eastern European Region, Journal of International Financial Markets, Institutions and Money, 18 (5) 483-497.

Tornyeva T, Tura A. H., Fatim, B (2012), Overview of Corporate Governance in Ethiopia: The Role, Composition and Remuneration of Boards of Directors in Share Companies Mizan Law Review: Vol. 6 No. 
Tornyeva, K. \&Wereko, T. (2012), Corporate Governance and Firm Performance. Evidence from Insurance Sector of Ghana. Journal of Accounting \& Finance, 13. Pp 95-112

Ujunwa, A., C. Okoyeuzu, I. Nwakoby (2012). Corporate Board Diversity and Firm Performance. Evidence from Nigeria, Review of International Comparative Management, 13 (4), pp. 605-620.

Wang, W.-K., Lu, W.-M., Lin, Y.-L., 2012. Does corporate governance play an important role in BHC performance? Evidence from the U.S. Econ.Model.29, 751-760. 